Janko Ramač

Univerzitet u Novom Sadu

Filozofski fakultet

Odsek za rusinistiku

ramacjanko@gmail.com
Originalan naučni rad

primljeno: 23. april 2014

prihvaćeno: 1. oktobar 2014

\title{
RUMUNI MEĐU PRVIM RUSINIMA U KRSTURU U XVIII VEKU*
}

Sažetak: U toku organizovanog doseljavanja Rusina u Bačku od sredine XVIII veka, u komorsko naselje Veliki Krstur - danas Ruski Krstur, zajedno sa Rusinima došlo je i nekoliko porodica Rumuna. U ovom radu se prati kada, kako i odakle su u Krstur stigle rumunske porodice, kakva je bila njihova verska pripadnost i kakva je bila njihova sudbina. pravoslavni.

Ključne reči: Veliki Krstur (Nagy Keresztúr), Ruski Krstur, Rusini, Rumuni, grkokatolici,

$\mathrm{Na}$ početku masovnije kolonizacije Bačke sredinom XVIII veka među kolonistima koji su tu naseljavani bili su i Rusini iz severoistočnih oblasti Ugarske, ${ }^{1}$ uglavnom sa teritorije 13 županija na koje se prostirala jurisdikcija grkokatoličke Mukačevske eparhije nad grkokatolicima. ${ }^{2}$ Podaci o prvim Rusinima doseljenim u Bačku dosta su šturi. Smatra se da su prvi rusinski doseljenici tu stigli kao sezonski radnici tražeći posao i zaradu, i da su se neki od njih, zadovoljni ovdašnjim prilikama, tu i naselili. ${ }^{3}$ Prvi Rusini naseljeni u Bačkoj spominju se u popisu stanovništva Kule iz 1746. godine: pored imena i prezimena prve trojice jasno je zabeležena i njihova nacionalna pripadnost: Ruthenus; posle ovih, iste godine zabeleženo je još 11 muškaraca, odnosno glava porodica, za koje se takođe izričito navodi da su Rusini i da su tu došli 1746. godine iz okoline Miškolca. ${ }^{4}$

\footnotetext{
* Текст је настао као фазни резултат рада на пројекту Војвођански простор у контексту европске историје (број 177002) Министарства просвете, науке и технолошког развоја Републике Србије. ${ }^{1} \mathrm{O}$ doseljavanju Rusina u Bačku sredinom XVIII veka vid.: Slavko Gavrilović, Rusini u Bačkoj i Sremu od sredine XVIII do sredine XIX veka, Godišnjak Društva istoričara Vojvodine, Novi Sad 1977, 153-215; Федор Лабош, История Русинох Бачкей, Сриму и Славониї 1745-1918, Вуковар 1979; Янко Рамач, Руснаци у Южней Угорскей (1745-1918), Нови Сад 2007.

2 Jurisdikcija grkokatoličke Mukačevske eparhije prostirala se na grkokatolike u sledećim severoistočnim županijama Ugarske: Ung, Ugoča, Bereg, Zemplin, Šariš, Spiš, Sabolč, Satmar, Maramoroš, Boršod, Gemer, Abau i Torna.

${ }^{3}$ S. Gavrilović, Nav. delo, 154; Ф. Лабош, Нав. дело, 58-59.

${ }^{4}$ S. Gavrilović, Nav. delo, 155: „Advenae anno 1746... Rutheni ex Partibus ad Miskolczinum“. Autor prvo navodi imena i prezimena prve trojice, i posle toga u fusnoti i spomenute jedanaestorice Rusina.
} 
Masovnije i organizovano naseljavanje Rusina u Bačku počelo je 1751. godine, kada je upravnik komorskih imanja u Bačkoj Franc Jozef de Redl potpisao kontrakt o naseljavanju u komorsko naselje Veliki Krstur / Nagy Keresztúr (od 1922. godine Ruski Krstur) 200 porodica Rusina grkokatolika iz gornjih krajeva Ugarske. ${ }^{5}$ I u kontraktu o naseljavanju Rusina u Kucuru iz 1763. godine, koji je bio sačinjen na latinskom jeziku, izričito stoji da se $\mathrm{u}$ ovo komorsko naselje mogu naseljavati samo Rusini grkokatolici/unijati sa pravom slobodnog preseljavanja - Rutheni hospites vere uniti liberae migrationis. ${ }^{6}$

Osnovni izvori na osnovu kojih se može sklopiti koliko-toliko jasna slika o naseljavanju i prvim doseljenicima Rusinima u Krstur od 1751. godine su već pomenuti kontrakt o naseljavanju iz 1751. godine, službeni popisi stanovništva u selu i druga komorska i županijska akta.

Prvi sačuvan popis stanovnika Krstura potiče iz 1752. godine. Tu su zabeležena 32 muškarca - glave porodica, i tačno se navodi da su prva osamnaestorica izvesno vreme živeli u Kuli, a na početku organizovanog naseljavanja Rusina u Krstur, po odobrenju komorskog upravnika J. Redla, preseljavaju se u Krstur kao prvi njegovi stanovnici; sledi 13 glava porodica onih koji su došli u Krstur 1751. godine, i na kraju su zapisani 29 muškaraca za koje se navodi da su došli u Krstur tokom 1752. godine. ${ }^{7}$ Među onima koji su se doselili u Krstur 1752. godine zabeležen je Vasilj/Vladislav Zagata Vasely/Ladislavus Zahata/Zakata, za kojeg se kasnije navodi da je Rumun iz Transilvanije. Komorski upravnik J. Redl u izveštaju Ugarskoj dvorskoj komori 1756. godine navodi da je među onima koji su se 1751. godine po njegovom odobrenju preselili iz Kule u Krstur bio i Vasilj Zagata sa dva sina, iz sela Santovo, iz županije Satmar. ${ }^{8}$ Za naše istraživanje nije od presudnog značaja dokazivanje da li je V. Zagata došao u Krstur 1751. ili 1752. godine, ali treba istaći da se postojeći izvori slažu u tome da je bio Rumun iz Transilvanije i da je u Krstur došao sa suprugom, dva oženjena sina i jednim maloletnim sinom. On je prvi među stanovnicima Krstura na početku ogranizovanog naseljavanja ovog komorskog naselja za koga se navodi da nije Rusin, odnosno da je Rumun.

Sama činjenica da je među Rusinima koji su se 1751/1752. godine naseljavali u Krstur bio i jedan Rumun sa dva odrasla sina i još dvojica Rumuna verovatno ne bi bila interesantna za istoričare da oni nisu imali istaknutu ulogu u nastojanju da Rusini grkokatolici pređu na pravoslavnu veru.

\footnotetext{
${ }^{5}$ Kopija kontrakta o naseljavanju Rusina u Krstur 1751. godine, na mađarskom jeziku, čuva se u Mesnoj kancelariji u Ruskom Krsturu. Original kontrakta nije pronađen, a sačuvana kopija kontrakta sačinjena je 7. novembra 1770. godine u Krsturu i overena potpisima i pečatima predstavnika Bačke županije Antonija Gomboša i Nikole Piukovića. U uvodnom delu i u prvoj tački kontrakta izričito se naglašava da je komorsko naselje, odnosno pustara Veliki Krstur, rezervisano za naseljavanje Rusina grkokatolika/unijata: „(...) az Kirali Coronalis Bacsi Districtusban levö Nagy Keresztur nevü Pusztának legalább 200 unitus Orosz Familiakkal való meg Szállettása resolváltatott (...). 1-mo. Engedtetik hogy azon lakosok kik kivant Pusztát meg Szálani kivánnyak mindnyájan unitus Oroszok legyenek“.

${ }^{6}$ Онуфриј Тимко, Насељеници Руског Крстура и Куцуре, Зборник за друштвене науке, 50, Нови Сад 1968 , $130-131$.

${ }^{7}$ Мирон Жирош, Бачванско-сримски Руснаци дома и у швеце 1745-1991, т. I, Нови Сад 1997, 30-32.

${ }^{8}$ Državni arhiv, Budimpešta (Országos levéltár, Budapest) (dalje: DAB), E-25: Informationes Cameralis Administrationis Bacsiensis, Redl, 7. septembra 1756. godine: „(...) Szakata Vasely vero una cum duobus filiis et duobus Valachis e Transilvania oriundis..."
} 
Posle 1752. godine, kada je zabeležen u popisu stanovnika Krstura, Vasilj Zagata se spominje u nizu dokumenata koji su nastali 1756. i 1757. godine, a odnose se na događaje u selu u vezi sa prelaskom nekih grkokatolika na pravoslavnu veru. Pored njega, u tim dokumentima se često spominju i njegovi sinovi, Nikola i Dimitrije, i još dvojica Rumuna, Luka Koroš i Jovan Vlah, svi poreklom iz Transilvanije. Nije jasno kako su ovi Rumuni došli u Kulu odnosno Krstur: da li direktno iz Transilvanije, što je, čini mi se, manje verovatno, ili su možda izvesno vreme bili u kontaktu, ili su i živeli među Rusinima u severoistočnoj Ugarskoj pa su se zajedno s njima ovde doselili. Takođe je moguće da su oni izvesno vreme boravili među Rusinima u Makou nedaleko od Segedina, gde je od početka XVIII veka postojala rusinska kolonija i odakle je u Krstur 1752. godine stigla jedna grupa Rusina. ${ }^{9}$ U matičnim knjigama grkokatoličke parohije u Makou prezime Oláh je veoma često kroz ceo XIX vek, spominje se i prezime Erdelyi, u šta smo se mogli lično uveriti 2010. godine zahvaljujući ljubaznosti mesnog paroha. Bilo kako bilo, smatramo da se ovi Rumuni ne bi duže zadržali među Rusinima u Krsturu da im je rusinski jezik bio potpuno stran i da odranije nisu bili u kontaktu sa Rusinima.

Podatke o Rumunima u Krsturu sredinom pedesetih godina XVIII veka crpimo iz izveštaja komorskog administratora J. Redla Ugarskoj dvorskoj komori i iz izjava ispitivanih učesnika i svedoka pred sudskim vlastima u vezi sa verskim nesporazumima $i$ sukobima između grkokatolika i pravoslavnih u Krsturu 1755. i 1756. godine, koje je u prevodu na rusinski jezik objavio Fedor Laboš. ${ }^{10}$

Bilo je pokušaja da se dokaže da su nesporazumi između grkokatolika i pravoslavnih u Krsturu počeli 1753. godine. Ipak, ta godina se ne može prihvatiti, jer je očigledno reč o antidatiranju dokumenata na koje se autor poziva. ${ }^{11}$ Odnosi između grkokatolika i pravoslavnih u Krsturu zaoštravaju se 1755. godine nastojanjem pravoslavnih da u selu podignu svoju crkvu i da sebi dovedu pravoslavnog sveštenika. Kao jedan od glavnih „krivaca“ za širenje pravoslavne vere među Rusinima grkokatolicima u selu označen je tadašnji krsturski grkokatolički sveštenik Mihajlo Keveždi. Posle provedenog isleđivanja, kaločki nadbiskup Ferenc Klobušicki je u julu 1755. godine naložio svom generalnom vikaru da sveštenika M. Keveždija odmah protera iz Krstura da ne zavodi narod. ${ }^{12}$ Nažalost, u spomenutom pismu se ne navodi precizno šta se pod tim ,zavođenjem naroda“ podrazumeva, ali mnogo konkretnije o svemu govori komorski upravnik J. Redl u svojim izveštajima Ugarskoj dvorskoj komori. Po njemu, problem je nastao kada je M. Keveždi sa još nekolicinom Rusina iz Krstura počeo da se sve češće sastaje sa pravoslavnim sveštenicima iz susednih sela. Tako se među Rusinima u Krsturu formirala jedna grupa pravoslavnih, onih koji su možda odranije ispovedali

\footnotetext{
${ }^{9}$ György Juhász, Emlék a makói gör. kath. templom felszentelési 100-ik évfordulójának jubileumára, Makon 1878,6 .

${ }^{10}$ Ф. Лабош, Нав. дело, 186-205.

11 Яким Сабадош, Походзенє и приход Руснацох до Бачкей, Шветлосц, 3, 4/1954, Руски Керестур 1954, 193-204, 269-280. U tom članku J. Sabadoš dokumente na koje se poziva, namerno ili greškom, antidatira i umesto 1756. navodi 1753. godinu. Čak i kada se poziva na članak Evgenija Džunje (Евґений Джуня, О нашим приселєню (Прилог нашей историї у XVIII вику), Шветлосц, 2, Руски Керестур 1952, 125-132), koji jasno navodi da je reč o dokumentu iz 1756. godine, Sabadoš to navodi pod 1753. godinom.

${ }^{12}$ AKA, bez signature - pismo kaločkog nadbiskupa Ferenca Klobušickog generalnom vikaru, Pešta, 20. jula 1755. godine: „Sacerdos ille Michael Kevezdi ex Keresztur immediate pellatur ne nobis populum seducat“.
} 
pravoslavnu veru, ili su već u Bačkoj prešli ili su hteli da pređu na pravoslavnu veru. Po navođenju J. Redla, sveštenik M. Keveždi, Rumun Vasilj Zagata i još neki pravoslavni Rusini išli su kod pravoslavnog bačkog episkopa Visariona Pavlovića da traže od njega pravoslavnog sveštenika i zaštitu, ali im je on odgovorio da oni kao unijati treba da traže sveštenika od svog mukačevskog episkopa. Verovatno da oni nisu očekivali takav odgovor od pravoslavnog episkopa, ali treba imati na umu činjenicu da je J. Redl još 1751. godine upozorio episkopa V. Pavlovića da je Krstur kao komorsko naselje rezervisan za grkokatolike i da se u njega može postaviti samo grkokatolički, ali ne i pravoslavni sveštenik. $^{13}$

U svom izveštaju Ugarskoj dvorskoj komori od 25. maja 1756. godine administrator J. Redl navodi da je opšta praksa u državi da se potpisani kontrakti smatraju za zakone i da se njihova reč mora poštovati. Zbog toga je smatrao da, pošto je u kontraktu o naseljavanju Krstura, koji je ratifikovala Ugarska dvorska komora, u prvoj tački navedeno da je Krstur određen za naseljavanje samo grkokatolika, a ne i pravoslavnih, ${ }^{14}$ trojica pravoslavnih: Mihal Sabo, Janko Kolar i Vasilj Zagata, koji su se na prevaru naselili u Krstur kao pripadnici pravoslavne vere, treba da se za dve nedelje isele u drugo komorsko naselje među pripadnike svoga obreda, a takođe i drugi, koji žive u Krsturu, a žele da ostanu u pravoslavnoj veroispovesti. ${ }^{15}$ Međutim, kada je Redl predložio da se trojica okrivljenih za izazivanje verskih nemira, Mihal Sabo, Janko Kolar i Vasilj Zagata, isele iz Krstura, stigla mu je molba sa potpisima 55 seljaka, koji su ga tražili da navedena trojica ne budu iseljena, jer su radili ne samo po svojoj volji nego u ime svih pravoslavnih u selu. Potpisnici molbe su upozoravali da, ako se stvarno ova trojica isele, onda će i svi oni u jesen, kada sakupe letinu, preći zajedno s njima u druga obližnja naselja među pravoslavne Srbe. ${ }^{16}$

Kasnije, u izveštaju Ugarskoj dvorskoj komori, J. Redl opširnije opisuje događaje u vezi sa jačanjem pokreta za prelaz grkokatolika na pravoslavnu veru i stvaranje uslova za organizovanje pravoslavne zajednice odnosno osnivanje crkvene opštine u Krsturu. On tvrdi da su se kao pravoslavni izjašnjavali uglavnom oni koji su se u Krstur doselili iz Kule, gde su izvesno vreme pre organizovanog naseljavanja Krstura živeli bez sveštenika svoje vere i tako se približili pravoslavnim Srbima. Kada je počelo naseljavanje u Krstur, ovi su izrazili želju da ostave svoje kuće u Kuli i da se presele u Krstur da bi tamo živeli zajedno sa svojim sunarodnicima koji su počeli da se tu organizovano doseljavaju. Redl navodi da im je predočio uslove za naseljavanje u Krstur i da su ih oni prihvatili. Među „korifeje“ pravoslavlja, između ostalih, Redl ubraja i Vasilja Zagatu sa dva sina. Za V. Zagatu kaže da je sa svoja dva sina i sa još dvojicom Rumuna iz Transilvanije odlazio u

\footnotetext{
${ }^{13}$ S. Gavrilović, Nav. delo, 158.

${ }^{14}$ DAB, E-szekció: Informationes cameralis administratoris Redl Ugarskoj dvorskoj komori, izveštaj od 25. maja 1756. godine: „Punctum Contractuale primum per Excelsam Cameram Caesareo-Regiam Huga[ari]co-Aulicam gratiose ratificatum (...) Praedium Nagykeresztur tantummodo pro unitis, nullatenus autem pro graeci ritus non unitis ex parte Cameralis hujus Dominii Bacsiensis assignatum fuit.“

${ }^{15}$ Isto: „(...) ideo, fraude ac dolo nemini patrocinate quaestionati graeci non uniti ritus tres hospites signanter Michael Sabo, Joannes Kollar et Zaghatas Vaszil ex Nagy Keresztur intra unius quindenae terminum ab hodierno dato computandum ad aliam eximam sui ritus Cameralem Possessionem semet cum p[rae]scitu D[omi]ni Provisoris Neszmer translocare noverint.“

${ }^{16}$ S. Gavrilović, Nav. delo, 159.
} 
srpska naselja kod pravoslavnih sveštenika. ${ }^{17}$ Ipak, Redl tvrdi da se od naseljavanja Rusina u Krstur 1751. godine sve do 1755. godine u selu nije praktikovala pravoslavna vera, i tek tada su V. Zagata sa svojim pristalicama i tadašnji paroh Mihajlo Keveždi i njegova supruga Srpkinja počeli da se sastaju sa pravoslavnima iz susednih naselja. ${ }^{18}$

U jesen 1756. godine, posle odlaska iz Krstura suspendovanog sveštenika $M$. Keveždija, J. Redl je tvrdio da je u selu ostalo samo nekoliko pravoslavnih, za koje je smatrao da se neće vratiti u grkokatoličku veru, a to su: Vasilj Zagata sa svoja dva sina, Nikolom i Dimitrijem, i još dvojica Rumuna koji su došli iz Transilvanije, Luka Koroš i Jovan Vlah, kao i Rusin Michal Sabo, i da ovi treba da se isele, pa više neće biti u selu verskih problema. ${ }^{19}$

U izveštaju Skupštine Bačke županije od 14. februara 1757. godine Namesničkom veću navodi se da je u Krsturu bilo nekoliko pravoslavnih, Srba i Rumuna, koji su se tajno, odnosno bez dozvole, naselili u Krstur, ali ih nema dovoljno da bi na osnovu carske rezolucije od 25. aprila 1753. godine mogli da podignu pravoslavni hram. ${ }^{20}$ Naime, prema toj rezoluciji, pravoslavnima je bilo dozvoljeno da podižu svoje hramove u mestima gde ih je bilo najmanje 30 porodica.

Pravoslavni u Krsturu su 1755. godine, uz podršku pravoslavnih sveštenika iz susednih sela, otpočeli akciju za podizanje pravoslavne crkve u selu. Izgleda da je oštriji sukob između pravoslavnih i grkokatolika u selu nastao upravo zbog crkve. Pravoslavni su kasnije tvrdili da su oni prvi došli u Krstur i da su počeli da grade pravoslavnu crkvu, ali da su ih komorske vlasti primorale da grade zajedničku crkvu sa grkokatolicima, a kada je crkva bila završena, grkokatolici nisu dozvoljavali da u nju dolaze i pravoslavni i da tu dovode pravoslavnog sveštenika. ${ }^{21}$ Ipak, teško je poverovati da su se predstavnici crkvenih vlasti grkokatolika, u ovom slučaju predstavnici Kaločke nadbiskupije, i predstavnici pravoslavne Bačke eparhije, odnosno Karlovačke mitropolije, složili da se u Krsturu gradi zajednička crkva za grkokatolike i pravoslavne, jer jednostavno takva praksa nije postojala. I ne samo da nije postojala praksa da rimokatolici i pravoslavni zajednički koriste neke hramove, već je poznato da je bilo velikih problema i da se u istim

\footnotetext{
${ }^{17}$ DAB, E-Szekció: Informationes cameralis administrattionis Bacsiensis, Redl - izveštaj administratora Redla Ugarskoj dvorskoj komori od 7. septembra 1756. godine: „(...) explicates que iisdem contractualibus conditionibus, relictis in loco Kulla etiam domibus suis, ad eandem cameralem possessionem Nagy Keresztur semet transocarunt, interquos taliter translocates, et actu principaliores coriphei, signanter: Szakata Vaszely cum duobus filiis, e possession Szanto, I. Comitatui Szakmariensi adjacent oriundus, Joannes Kollar (...) Szakata Vaszely vero una cum duobus filiis et duobus Valachis e Transilvania oriundis, primaevus assidue per pagos Rascianicos obierrat, et quacumque ab incolis N. Keresturiensisbus audit, et circa eorundem ritumodservat, poponibus graeci non uniti Ritus refert“"

${ }_{18}$ Isto: ,(..) ab anno 1751-o impopulatum populum Nagy Kereszturiensem nohn nisi Anno 1755-to indubie subsecutorum observabantur Schisma, eh quo in specie: Szakata Vasely, cum nonnulibus mentionatis suis asseclis, una cum loci protunc parocho, Michaele Kövessdy nuncupato, cum muliere e natione Illyrica copulato, cum graeci non uniti Ritus vicinis coincolis consilia sua ad invicem communicaverint, sociatatemque cum Schismaticis servaverint".

${ }^{19}$ Isto: „(...) Vasely Szakata vero, cum duobus, Nicolaus et Demetrio filiis, antehanc indubie unitis, de certis item duobus Valachis, nomine Luca et Jovan e Transilvania oriundis, nec non Michael Szabo, in unione permansuris, pro hic et nunc nulla super spes“.

${ }^{20}$ Isto; DAB, E-Szekció: Informationes cameralis administrattionis Bacsiensis, Redl - Izveštaj Ugarskom namesničkom veću od 14 . februara 1757 . godine.

${ }^{21}$ S. Gavrilović, Nav. delo, 158.
} 
hramovima obavljaju bogosluženja za rimokatolike i grkokatolike. ${ }^{22}$

Kada se sukob između pristalica grkokatoličke i pravoslavne vere već znatno rasplamsao, predstavnici Kaločke nadbiskupije i komorske vlasti nastojali su da ga smire, podržavajući grkokatolike, uvek se pozivajući na kontrakt o naseljavanju u kom je bilo striktno navedeno da je komorsko naselje Krstur rezervisano za Rusine grkokatolike. ${ }^{23}$

Pošto su se sukobi zaoštrili, komorske i županijske vlasti poslale su u selo sudske organe i komisije da utvrde faktičko stanje i da pronađu i kazne krivce koji su odgovorni za izazivanje verskih nemira i nereda. Ne ulazeći dublje u sukobe između pravoslavnih i grkokatolika u Krsturu i ne spominjući ovde sve pritiske crkvenih i komorskih vlasti na pravoslavne, o čemu je već dosta pisano, ${ }^{24}$ treba istaći da je sve to značajno uticalo na smanjenje broja pristalica pravoslavne vere. U jednom dokumentu iz 1757 . godine navodi se da je komisija, nastojeći da utvrdi tačan broj pravoslavnih (ako bi ih bilo 30 domova, imali bi pravo da grade svoju crkvu), ustanovila da se broj pravoslavnih smanjio: 14 od onih koji su se ranije izjasnili da žele da pređu na pravoslavnu veru izjasnilo se za vraćanje na grkokatoličku veru, a samo osmorica Rusina i petorica Rumuna/Vlaha izjasnili su se kao pravoslavni. Od Rumuna to su: Sima Vlah, Luka Koroš, Starac (Vasilj) Zagata, Nikola Zagata i Jovan Vlah. ${ }^{25}$

Posle toga, u leto 1757. godine u Krstur je stigla nova komisija koja je ispitala 13 muškaraca koji su pre toga izjavili da su pravoslavne vere ili da žele da pređu na pravoslavnu veru. Među ovima je bio i Nikola Zagata, sin Vasilja Zagate. Nikola je tada imao oko 30 godina, i prema izjavi, u Krstur je došao sa imanja Santovo u Transilvaniji. Ispovedao je pravoslavnu veru i bio je oženjen Rusinkom koja je rođena i odgojena $\mathrm{u}$ grkokatoličkoj veri. ${ }^{26}$ Posle toga je ispitano još sedam svedoka, da bi se događaji u vezi sa verskim nemirima i sukobima u Krsturu što podrobnije ispitali. Prvi svedok je bio Mihajlo Munkači, libertin, koji je 1751. godine doselio Rusine u Krstur. Prema njegovoj izjavi, nekoliko Rusina iz Krstura se još 1751. ili 1752. godine obratilo bačkom episkopu Visarionu Pavloviću, moleći ga da im da pravoslavnog sveštenika, ali on nije hteo. Posle smrti episkopa Visariona nekoliko Rusina iz Krstura, među njima i Vasilj Zagata, obratilo se mitropolitu u Karlovcima tražeći od njega da im pošalje pravoslavnog sveštenika, i uspeli su u tome. Taj sveštenik je bio na stanu kod Vasilja Zagate. Skoro identične izjave su davali i drugi svedoci, navodeći da je Vasilj Zagata bio među onima koji su najviše radili na tome da Rusini grkokatolici pređu na pravoslavnu veru. ${ }^{27}$

Posle prvih ispitivanja 32 Rusina, koji su se izvesno vreme izjašnjavali kao pravoslavni, ili da žele da pređu na pravoslavnu veru, obratili su se generalnom vikaru Kaločke nadbiskupuje Emeriku Noršiću izjavljujući da žele da se vrate na grkokatoličku

\footnotetext{
${ }^{22}$ Kada su krajem XVIII veka Nemci počeli da se u sve većem broju naseljavaju u Kucuru, generalni vikar Kaločke nadbiskupije Martin Takač se obratio grkokatoličkom parohu u Kucuri Luki Stašinskom i molio ga da dozvoli da se u grkokatoličkoj crkvi u selu mogu obavljati bogosluženja za rimokatolike, ali ovaj nije dozvolio. Detaljnije o tome: Я. Рамач, Руснаци у Южней Угорскей..., 125.

${ }^{23}$ S. Gavrilović, Nav. delo, 157-163.

${ }^{24}$ Isto.

${ }^{25}$ Ф. Лабош, Нав. дело, 186-187; S. Gavrilović, Nav. delo, 161.

${ }^{26}$ Ф. Лабош, Нав. дело, 192.

${ }^{27}$ Isto, 195-198.
} 
veru i da ostanu u njoj. ${ }^{28}$ Odmah posle toga u Krsturu su ispitana pred komisijom još sedmorica, među njima kao prvi Vasilj Zagata. U toj izjavi on daje mnogo podataka o sebi i o svojoj delatnosti u vezi sa nastojanjem da se u Krsturu osnuje pravoslavna crkvena opština i da Rusini grkokatolici pređu na pravoslavnu veru. Zagata je tada imao oko 70 godina. Navodio je da je u Krstur došao iz sela Santovo u Transilvaniji sa ženom, dvojicom oženjenih sinova i jednim neoženjenim. Ispovedao je pravoslavnu veru, jer su mu i otac i deda bili pravoslavni. Dalje je navodio da je u Krstur došao pre pet godina sa poseda Pejakovo i predstavio se kao grkokatolik. Tada je čuo od krsturskog sveštenika Mihajla Keveždija da mu je bački episkop obećao da će mu dati blagoslov ako Rusini grkokatolici pređu na pravoslavnu veru. Zbog toga je Vasilj odlučio da se trajno nastani u Krsturu. Priznao je i da je 1756. godine bio kod mitropolita u Karlovcima i da ga je molio da mu isposluje otpusno pismo da se iseli iz Krstura, jer ne želi da pređe na grkokatoličku veru. Dalje navodi da ga je mitropolit savetovao da ostane u Krsturu i da svi oni koji se drže pravoslavne vere istraju u tome. Posle toga je oko 30 muškaraca potpisalo pismo mitropolitu u Karlovcima i obećalo da će ostati u pravoslavnoj veri. Kasnije su se Rusini iz Krstura susreli sa mitropolitovim egzarhom u Kuli i tada ih je bilo već oko 50. Posle toga jedna delegacija je ponovo išla kod mitropolita u Karlovce, kada im je on obećao da će im iz Beča isposlovati pravo/privilegiju da mogu da u selu podignu pravoslavnu crkvu i da će im postaviti pravoslavnog sveštenika. Nakon toga je u Krstur stigao pravoslavni sveštenik iz Pivnica i tvrdio je da već ima tu privilegiju. ${ }^{29}$ Po svemu sudeći, V. Zagata je u svojoj izjavi davao istinite podatke, jer se njegove tvrdnje uglavnom poklapaju sa izjavama učesnika i svedoka o tim događajima, kao i ranijim podacima u izveštajima kompetentnih vlasti.

Drugi izvor koji daje neke podatke o Rumunima u Krsturu u XVIII veku i prvoj polovini XIX veka su popisi stanovništva. Istina, u tim popisima nikad nije beležena verska ili nacionalna pripadnost stanovnika, ali su tu imena i prezimena onih Rumuna za koje se u već spominjanim izvorima izričito navodi da su Rumuni/Valachi/Vlasi.

U popisu stanovništva Krstura iz 1752. godine V. Zagata je zabeležen među onima koji su u selo došli te godine. Tu nisu zabeležena njegova dva odrasla sina, jer su verovatno tada još bili u zajedničkom domaćinstvu sa svojim ocem. Naime, u izjavi 1757. godine V. Zagata navodi da je došao u Krstur sa suprugom, dva oženjena sina i jednim neoženjenim sinom.

U popisu iz 1756/57. godine, kao i u kasnijim popisima, V. Zagate nema, a ne nalazimo ni podatke o tome da li se iselio ili je možda umro. U tom popisu zabeleženi su i oni Rumuni koji su se 1757. godine izjasnili da žele da ostanu verni pravoslavnoj veri: Joan Vlah / Janoš Vla, Nikola Zagata, Luka Koroš i Dimitrije Zagata, a pored imena Nikole i Dimitrija Zagate stoji i napomena: žele da se presele u Pivnice. ${ }^{30}$

U popisu stanovništva Krstura iz 1762. godine zabeleženi su Rumuni koji su imali kuće: Janos Vlach, 40 g., oženjen, supruga 23 g., imaju 4 kćeri (red. br. 61); Jovan Vlach, 38 g., oženjen, supruga 22 g., nemaju dece (red. br. 75); Jovan Vlach , 55 g.,

\footnotetext{
${ }^{28}$ Isto, 198-200.

${ }^{29}$ Isto, 202-203.

${ }^{30}$ М. Жирош, Нав. дело, 34-38.
} 
oženjen, supruga 46 g., imaju dva sina i dve kćeri (red. br 135); Marian Vlach, 50 g, oženjen, supruga 30 g., nemaju dece (red. br. 194); među želirima je Krascon Vlach, 30 g., oženjen, supruga 50 g., nemaju dece (red. br. 9). ${ }^{31} \mathrm{U}$ ovom popisu navedena su trojica $\mathrm{s}$ imenom i prezimenom Jovan/Janoš Vlach, ali na osnovu njihovih godina može se sa velikom sigurnošću zaključiti da nije reč o najužoj rodbini, odnosno da to nisu otac i sinovi.

U popisu stanovnika Krstura koji su se doselili 1763. godine zapisani su sledeći Rumuni: Janko Erdelj, oženjen, imaju 6 dece (red. br. 20); Andrij Ola, oženjen, imaju jedno dete (red. br. 68), a Katrin Ola je među onima koji nemaju vlastite kuće, oženjen, nemaju dece (red. br. 58). ${ }^{32}$

U popisu onih koji su se iselili iz Krstura 1763. i 1764. godine navedeni su: Janko Vlach, 40 g., oženjen, supruga 23 g., imaju 4 kćeri (red. br. 61 u popisu iz 1762); Jovan Vlach, 55 g., oženjen, supruga 46 g., imaju dva sina i dve kćeri (red. br. 135 u popisu 1762). ${ }^{33}$ Iz ovih podataka vidi se da se Jovan Vlah, zabeležen u popisu iz 1762. godine pod rednim brojem 75 , posle toga ne navodi ni u popisu stanovnika Krstura iz 1763. godine, a nije ni na spisku onih koji su se 1763. i 1764. godine iselili iz Krstura. Može se samo pretpostaviti da je u međuvremenu umro.

U popisu stanovništva Krstura koji je urađen 29. decembra 1764. godine zabeleženi su među onima koji imaju kuće: Joannes Vláh, oženjen, imaju jedno dete (red. br. 2); Joannes Erdély, oženjen, imaju šestoro dece (red. br. 56) i Andreas Olá, oženjen, imaju jedno dete (red br. 185), a među onima koji nemaju svoje kuće zabeleženi su: Kracscun Olá, oženjen, imaju jedno dete (red. br. 185), Katrin Olá, oženjen, nemaju dece (red. br. 166), i Marian Vláh, oženjen, imaju dvoje dece (red. br. 199). ${ }^{34}$ Ipak, to što se u popisu stanovništa iz decembra 1764. godine spominje Janko Vlah, koji živi u domaćinstvu sa suprugom i jednim detetom, a ne navodi se u spisku među onima koji su se doselili u Krstur 1763. godine, ne mora da znači da se u Krstur vratio jedan od dvojice s tim imenom i prezimenom koji su se 1763. i 1764. godine iselili iz Krstura, a jedan Jovan Vlah se spominje u Obrovcu u martu iste godine, i navodi se da se tu doselio iz Krstura. Možemo pretpostaviti da je reč o sinu Jovana Vlacha zapisanog pod red. br. 135, koji je imao dva sina i dve kćeri. Ovakva pokretljivost stanovništva i česta preseljavanja nisu neka specifičnost Rumuna koji su se se naselili u Krstur od 50-70-ih godina XVIII veka, to je bilo karakteristično i za Rusine u Bačkoj u tom periodu. ${ }^{35}$

U vreme organizovanog naseljavanja Rusina u Kucuru 1763. godine priličan broj Rusina iz Krstura preseljava se u ovo komorsko naselje. Smatra se da su se mnogi iz Krstura preselili u Kucuru nadajući se da će lažnim predstavljanjem kao novi doseljenici moći da koriste pogodnosti tzv. slobodnih godina, za vreme kojih novi kolonisti ne plaćaju neka davanja vlasniku zemlje i županiji. Ipak, u popisima stanovnika Kucure iz tih godina nismo pronašli nijednog od onih Rumuna/Vlaha koji su se ranije spominjali u Krsturu. U

\footnotetext{
${ }^{31}$ Isto, $41-47$.

${ }^{32}$ Isto, 51-55.

${ }^{33}$ Isto, 60-62.

${ }^{34}$ Isto, $73-83$.

${ }^{35}$ Pokretljivost i česta preseljavanja Rusina koji su došli u Bačku od 50-70-ih godina XVIII veka najbolje je dokumentovao analizirajući pojedine popise stanovnika Krstura i Kucure Miron Žiroš: М. Жирош, Нав. дело.
} 
to vreme se iz Krstura pojedinci ili manje grupe iseljavaju i u druga naselja. Jedno od njih bio je Obrovac. Zbog toga su po nalogu kaločkog nadbiskupa u martu 1764. godine popisani grkokatolici koji su se preselili u ovo naselje. Tada je u Obrovcu popisano ukupno $25 \frac{1}{2}$ porodica grkokatolika. Od ovih 17 1/2 porodica bili su Rusini koji su se u Obrovac doselili iz Krstura, ali i iz Nađ Karolja i iz županija Boršod, Sabolč i Zemplin. Na kraju je zapisano 8 porodica za koje se navodi da su poreklom Rumuni - origine Valachi, da su došli iz Transilvanije, da su u Krsturu stupili u brakove sa grkokatolikinjama i da i sami ispovedaju grkokatoličku veru, a to su: Petrus Manny, Petrus Erdelyi, Prokopia Vla sa dva mala sina, Jovan Vlah, Szima Vla, Sima Vla, Koszma Vla i Jovan Vla. ${ }^{36}$

Posle toga u popisima stanovnika Krstura do kraja XVIII i u prvoj polovini XIX veka nalazimo samo nekoliko rumunskih prezimena - to su oni, odnosno potomci onih, za koje se u već spomenutim izvorima iz 50-ih i 60-ih godina XVIII veka navodi da su Rumuni poreklom iz Transilvanije.

Havrijil Kosteljnik navodi da su se Rusini i Rumuni koji su se preselili iz Krstura u Obrovac, i tu su popisani 1764. godine, kasnije vratili u Krstur, a da su se ti Rumuni vremenom potpuno rusinizovali, jer su porodice s prezimenom Vlah, Manjoš i Erdelji prisutne u Krsturu od druge polovine XVIII sve do početka XX veka. ${ }^{37}$

Međutim, očigledno je da se nisu svi Rusini i Rumuni popisani u Obrovcu 1764. godine odmah vratili u Krstur, jer su neki od njih, njihovi potomci ili neki koji su kasnije iz Krstura otišli u Obrovac, zabeleženi u Urbaru sela Obrovca 1772. godine, a to su: Thodor/ Franciscus Koszta, Jovan Moszkál / Joan Muszka, Janoš/Janko Homa, Luka Koross, Joan Koleszar, Jovan Rusz, Jovan Vla, Kracsun Vlah i Michál Rácz. ${ }^{38}$ Grkokatolika u Obrovcu bilo je i na početku XIX veka: 1810. godine ukupno 14, a 1825. godine - 12, ali nisu poznati bliži podaci o njima. Posle toga do sredine XIX veka grkokatolici u Obrovcu više se ne spominju. ${ }^{39}$

U popisu stanovnika Krstura iz 1765. godine od Rumuna koji imaju kuće zabeležen je Jovan Erdulan, oženjen, imaju šestoro dece (red. br. 56), a među onima koji nemaju vlastite kuće: Janya Vláh, oženjen, imaju dvoje dece (red. br. 98), i Andria Vlá, oženjen, imaju jedno dete. (red. br. 187). ${ }^{40}$ Ovde svakako treba napomenuti da ima izvesnih razlika u pisanju ličnih imena i prezimena od popisa do popisa. To nije čudno ako se zna da su popisivači kao državni činovnici praktično bili pripadnici svih naroda koji su živeli u Ugarskoj odnosno u Monarhiji i da su pojedinci na različite načine i različitim pravopisima zapisivali imena i prezimena pripadnika pojedinih naroda. Na to sam ukazao i prilikom publikovanja odgovora na devet pitanja prilikom urbarske regulacije i uvođenja Ugarskog urbara iz 1767. godine u pojedinim naseljima u Bačkoj sedamdesetih godina XVIII veka. ${ }^{41}$ Tako, na primer, prezime Vlah se nalazi zapisano u nekoliko varijanti: Vlah,

\footnotetext{
${ }^{36}$ Havrijil Kosteljnik navodi imena i prezimena pomenutih na rusinskom jeziku: Гавриїл Костельник, Liber тетоrabilium грекокатолӥикей парохиї бачкерестурскей. Нови Сад 1998, 26, а ја ovde navodim prema originalnom dokumentu iz Arhiva Kaločke arhiepiskopije, bez signature, Obrovac, 31. marta 1764. godine.

${ }^{37}$ Г. Костельник, Нав. дело, 26-27.

${ }^{38}$ Muzej Vojvodine, inv. br. 860: Obrovácz Szela Urbarium - Urbar Obrovca iz 1772. godine.

${ }^{39}$ S. Gavrilović, Nav. delo, 180.

${ }^{40}$ М. Жирош, Нав. дело, 84-94.

${ }^{41}$ Јанко Рамач, Прилог проучавању урбарске регулаиије у Бачкој 1770. године - одговори на девет
} 
Vlach, Vláh, Vlá, Olah, Olá. Prezime Erdelji zapisano 1764. i 1765. godine u dve varijante: Erdelyi i Erdulan. A da je reč o istoj osobi, lako je dokazati: u popisu stanovništva Krstura iz 1764. godine pod rednim odnosno kućnim brojem 56 zapisan je Jovan Erdelji, koji ima šestoro dece, a u popisu stanovništva u selu sledeće godine pod rednim/kućnim brojem 56 zapisan je Jovan Erdulan koji ima šestoro dece.

U popisu stanovnika Krstura po ulicama iz 1770. godine zapisani su Joannes/Janko Oláh (Nagy šor, red. br. 38), ima 50 godina, supruga Maria 42 g., i deca: Michael 17 g., Joannes 15 g., Basilius 10 g. i Anna 4 g., i Andr[ija] Olah (Budžak šor, red. br. 26), 49 g., supruga Maria 38 g., i deca: Anna 8 g. i Maria 4 g. ${ }^{42}$

U urbarijalnom popisu stanovnika Krstura iz 1770. godine zabeleženi su među onim seljacima koji imaju zemlju Rumuni Janos Oláh (red. br. 96) i Janyo Oláh (red. br. 249), a među inkvilinima - onima koji nemaju vlastitu kuću, a imaju zemlju - Andria Vláh (red. br. 284), a Joška Vlah (red. br. 312) među subinkvilinima - onima koji nemaju ni kuću ni zemlju. ${ }^{43}$

U urbarijalnoj tabeli iz 1772. godine nalaze se upisani sledeći Rumuni: seljak Janos Olah (red. br. 88), inkvilin Andrija Vlah (red. br. 10), i subinkvilin Joška Olah (red. br. 17). U urbarijalnoj tabeli iz 1783. godine zapisna su tri Rumuna: seljaci Jovan Erdeljan (red. br. 8) i Janos Manyos (red. br. 104) i želir Joska Olah, koji nema zemlju, ali ima kuću (red. br. 32). ${ }^{44}$

U državnom popisu iz 1828. godine u Krsturu je popisano šest rumunskih porodica: Janko Erdelji, živeo je sam u domaćinstvu (red. br. 17), ${ }^{45}$ Petro Erdelji, ima ih četvoro u domaćinstvu (red. br. 125), Đura Olah, ima ih troje u domaćinstvu (red. br. 164), Janko Manjoš, ima ih četvoro u domaćinstvu (red. br. 214), Miška Olah, dvoje u domaćinstvu (red. br. 332), Janko Manjoš Ml., ima ih troje u domaćinstvu (red. br. 439). ${ }^{46}$

U urbarijalnom popisu stanovnika Krstura iz 1848. godine navode se podaci o posedu pojedinih domaćinstava i o njihovim urbarijalnim obavezama, ali nema podataka o broju članova porodica odnosno domaćinstava. U tom popisu zabeležene su četiri porodice Erdelji, dve porodice Manjoš i dve porodice Olah. ${ }^{47}$

Neposredno posle doseljavanja Rusina u Bačku, kada su oni kao grkokatolici bili stavljeni pod crkvenu jurisdikciju rimokatoličke Kaločke nadbiskupije, u rešavanju njihovih obrednih pitanja i sam nadbiskup se obraćao za pomoć mukačevskom grkokatoličkom episkopu ili je upućivao Rusine iz Krstura i Kucure na Mukačevsku eparhiju, u kojoj su Rusini činili većinu vernika, ili u Velikovaradinsku grkokatoličku eparhiju, u kojoj su Rusini bili u manjini u odnosu na rumunsku većinu. Među Rusinima koji su se 50-60-ih godina XVIII veka naselili u Krstur i Kucuru bilo je i onih koji su tu

\footnotetext{
питања, Истраживања, 21, Нови Сад 2010, 113-166.

${ }^{42}$ AKA, bez signature - popis stanovništva Krstura po ulicama iz 1770. godine. U popisu su zavedeni svi koji su živeli u domaćinstvu, i odrasli i deca, sa navođenjem godina starosti svakoga. Popis je objavio M. Žiroš: Жирош, Нав. дело, 129-157, ali u prevodu sa latinskog na rusinski jezik, pa i imena i prezimena piše na rusinskom jeziku, a mi ovde prenosimo onako kako stoji u originalnom dokumentu.

${ }^{43}$ Isto, $161-173$.

${ }^{44}$ Isto, 177-213.

${ }^{45}$ Prema tom popisu računaju se samo osobe od 18 do 60 godina.

${ }^{46}$ М. Жирош, Нав. дело, 266-276.

${ }^{47}$ Isto, 301-315.
} 
došli sa teritorije na kojoj je jurisdikciju nad grkokatolicima imala grkokatolička eparhija u Velikom Varadinu. Tu su Rusini bili u kontaktu sa Rumunima, zato nije čudno da je nekoliko porodica Rumuna došlo u Krstur i Kucuru među Rusine i da su neki od njih tu i ostali. Ipak, pošto su tu bili u manjini, vremenom su se potpuno asimilovali među rusinskom većinom, pa je na početku XX veka među Rusinima u Krsturu ostalo samo sećanje da su porodice Manjoš, Vlah/Olah i Erdelji rumunskog porekla. ${ }^{48}$ A neke rumunske porodice, kao Zagata i Koroš, spominju se samo 50-ih godina XVIII veka. Izgleda da su se iz Krstura iselile one rumunske porodice koje su bile pravoslavne vere. U popisu stanovništva Krstura iz 1756/1757. godine pored imena Nikole i Dmitra Zagate stoji napomena da žele da se presele u Pivnice, ${ }^{49}$ a posle toga se ni oni ni neko s tim prezimenom ne spominju u Krsturu.

Iz vremena doseljavanja Rusina u Bačku 50-60-ih godina XVIII veka ima malo podataka, tako da se o mnogim stvarima može rasuđivati ili donositi zaključci i na osnovu analogija. Kosteljnik je na početku XX veka pisao da su porodice rumunskog porekla sa prezimenima Erdelji, Vlah i Manjoš tada već bile potpuno asimilovane odnosno rusinizovane. Čini nam se da su se oni Rumuni koji su se naselili u Krsturu, tu ostali i ispovedali grkokatoličku veru, relativno brzo asimilovali. Može se pretpostaviti da su oni koji su se ovde doselili zajedno sa Rusinima već u starom zavičaju bili u kontaktu s njima i da su znali odnosno razumeli rusinski jezik. A u novoj sredini, pošto ih je bilo samo nekoliko porodica, u svakodnevnom kontaktu sa Rusinima teško su mogli da se odupru prirodnoj asimilaciji. Takođe je verovatno, mada o tome nema sigurnih podataka, da su i neki Rusini koji su živeli $u$ istim naseljima sa Rumunima razumeli ili znali rumunski jezik. Prema podacima iz popisa parohija Mukačevske eparhije iz 1806. godine Rusini i Rumuni su živeli u istim parohijama odnosno filijalama najviše u županijama Satmar, Sabolč, Maramoroš i Ugoča, ali i u nekim drugim. ${ }^{50}$ U zapisniku o kanonskoj vizitaciji parohije u Krsturu iz 1767. godine navodi se da je grkokatolički sveštenik Dimitrij Popović pored svog maternjeg rusinskog znao i mađarski i rumunski jezik, ${ }^{51}$ a na samom početku XIX veka učitelj u rusinskoj konfesionalnoj školi u Krsturu bio je Đura/Georgije Olah/Vlah, koji je verovatno bio poreklom Rumun. ${ }^{52}$

Na kraju zaključak: kada su se Rusini iz severoistočnih županija Ugarske sredinom XVIII veka počeli organizovano naseljavati u Bačku, prvo u Krstur 1751. godine, a od 1763. godine i u Kucuru, sa njima je došlo i nekoliko porodica Rumuna, koji su uglavnom bili pravoslavne vere. Pošto je kontraktom o naseljavanju Rusina u Krstur bilo određeno da se u ovo komorsko naselje mogu naseljavati samo Rusini grkokatolici, komorske i županijske vlasti su insistirale da se oni, za koje se ustanovilo da su pravoslavne vere, isele ili da pređu na grkokatoličku veru. Tako su se neki, koji su želeli da ostanu u pravoslavnoj veri, iselili u druga susedna naselja među pravoslavne Srbe, a oni koji su prihvatili grkokatoličku veru, pošto su tu bili u manjini, relativno brzo su se

\footnotetext{
${ }^{48}$ Г. Костельник, Нав. дело, 27.

${ }^{49}$ М. Жирош, Нав. дело, 37.

${ }^{50}$ István Udvari, A munkácsi görögkatolikus püspökség lelkészégeinek 1806. évi összeírása, Nyíregyháza 1990.

51 Янко Рамач, Канонічна візитація Керестурської парафії 1767 року, Науковий збірник Музею української культури у Свиднику, 25, Свидник 2010, 98.

52 Янко Рамач, Школа у Руским Керестуре (1753-1918), Нови Сад 1995, 41.
} 
asimilovali među rusinskom većinom. Na početku XX veka u Krsturu je ostalo samo sećanje da su porodice Erdelji, Manjoš i Vlah rumunskog porekla.

Izvori i literatura:

AKA - Arhiv Kaločke arhiepiskopije, Kaloča, fascikla: Grkokatolici.

DAB - Državni arhiv, Budimpešta (Országos levéltár, Budapest), E-szekció: Informationes cameralis administrationis Bacsiensis, Redl - Izveštaji komorskog administratora Redla Ugarskoj dvorskoj komori, 1756. g.

MV - Muzej Vojvodine, Novi Sad - Urbar Obrovca iz 1772. godine, inv. br. 860.

Gavrilović, Slavko, Rusini u Bačkoj i Sremu od sredine XVIII do sredine XIX veka, Godišnjak Društva istoričara Vojvodine, Novi Sad 1977, 153-215.

Джуня, Евгений, О нашим приселєню (Прилог намей историї у XVIII вику), Шветлосц, 2, Руски Керестур 1952, 125-132.

Жирош, Мирон, Бачванско-сримски Руснаци дома и у швеце 1745-1991, т. I, Нови Сад 1997.

Juhás György Gy. Emlék a makói gör. kath. templom felszentelési 100-ik évfordulójának jubileumára, Makon 1878.

Костельник, Габор Значенє Керестура, Руски календар за южно-славяньских Русинох на прости рок 1925, Руски Керестур 1924, 58-72.

Костельник, Г., Liber тетоrabilium грекокатолӥикей парохиї Бачкерестурскей. Нови Сад 1998.

Лабош, Федор, История Русинох Бачкей, Сриму и Славониї 1745-1918, Вуковар 1979.

Рамач, Янко, Школа у Руским Керестуре (1753-1918), Нови Сад 1995.

Рамач, Янко, Руснаци у Южней Угорскей (1745-1918), Нови Сад 2007.

Рамач, Янко, Канонічна візитачія Керестурської парафії 1767 року, Науковий збірник Музею української культури у Свиднику, 25, Свидник 2010, 95-128.

Рамач, Јанко, Прилог проучавању урбарске регулащије у Бачкој 1770. године - одговори на девет питања, Истраживања, 21, Нови Сад 2010, 113-166.

Сабадош, Яким, Походзене и приход Руснащох до Бачкей (I-II), Шветлосц, 3, 4/1954, Руски Керестур 1954, 193-204, 269-280.

Тимко, Онуфриј, Насељеници Руског Крстура и Куиуре, Зборник за друштвене науке, 50, Нови Сад 1968, 129-142.

Udvari István, A munkácsi görögkatolikus püspökség lelkészégeinek 1806. évi összeirása, Nyíregyháza 1990. 


\title{
THE RUMANIANS AMONG THE FIRST RUTHENIANS WHO SETTLED BAČKA AROUND THE $18^{\text {TH }}$ CENTURY
}

\begin{abstract}
Summary
The paper elaborates the period of the first organised immigration of the Greek Catholic Ruthenians from the north-eastern districts of Hungary to Kerestur in Bačka, which at that time was called Nagy Keresztur (Ruski Krstur today), with whom also came some Orthodox Rumanians. Since by the settlement contract only Greek Catholic Ruthenians were allowed to settle there from 1751 onward, the district authorities did not allow the Orthodox Rumanians to stay at the same place. Because of that, some Rumanians moved to other settlements to live side by side with the Orthodox Serbs, while some accepted the Greek Catholic faith and stayed in Kerestur.

This paper, using the data from the census taken in Kerestur, traces the number of the Rumanians from the second half of the $18^{\text {th }}$ to the middle of the $19^{\text {th }}$ century, when there were eight Rumanian families living in the village. At the beginning of the $20^{\text {th }}$ century the citizens of Ruski Krstur only vaguely remembered that the families Erdelji, Manjos and Vlah were of Rumanian origin, because they had been completely assimilated by that time.
\end{abstract}

Keywords: Veliki Kerestur/Nagy Keresztur/Ruski Krstur, Ruthenians, Rumanians, Greek Catholics, the Orthodox. 